Original Research

\title{
Assisted Phytostabilization of Acidic Polymetallic Mine Tailings Using Marble Waste and Native Plant Citrullus colocynthis: Effect on Soil, Plant, and Metal Uptake
}

Laila Midhat ${ }^{1,2,{ }^{+}}$, Naaila Ouazzani ${ }^{1,2,{ }^{\dagger}}$, Abdessamed Hejjaj ${ }^{1,{ }^{+}}$, Ahmed Ouhammou ${ }^{3,{ }^{\dagger}}$, Laila Mandi $1,2,+$, *

1. National Center for Research and Studies on Water and Energy, CNEREE, Cadi Ayyad University, PO 511, Marrakech, Morocco; E-Mails: laila.midhat@gmail.com; ouazzani@uca.ac.ma; a.hejiaj@uca.ma; mandi@uca.ac.ma

2. Laboratory of Water, Biodiversity and Climate Change, Faculty of Sciences Semlalia, Cadi Ayyad University, PO 2390, Marrakech, Morocco

3. Laboratory of Environment and Ecology (L2E, CNRST Associated Research Unit, URAC 32), Regional Herbarium MARK, Faculty of Sciences Semlalia, Cadi Ayyad University, Marrakech, Morocco; E-Mail: ouhammou@gmail.com

+ These authors contributed equally to this work.

* Correspondence: Laila Mandi; E-Mail: mandi@uca.ac.ma

Academic Editor: Meshari Almutairi

Special Issue: Materials and Method for Soil Remediation

Recent Progress in Materials

2021, volume 3, issue 3

doi:10.21926/rpm.2103030
Received: December 29, 2020

Accepted: July 05, 2021

Published: July 23, 2021

\section{Abstract}

This study aimed to assess the effectiveness of the phytostabilization ability of the native Moroccan plant Citrullus colocynthis on the neutralization of soil acidity and stabilization of metallic trace elements (MTEs) assisted by marble waste. Mine tailings (MT) collected from an abandoned polymetallic site were mixed with powdered marble (PM) using different mixing ratios (\%): (MTPM $\left.{ }_{25}\right)$, (MTPM $\left.{ }_{50}\right),\left(M_{T P M}\right)$, and agricultural soil (AS) acting as the control. Seeds of $C$. colocynthis were selected and planted under greenhouse conditions. Growth parameters were measured, and the metal concentrations in substrates and plant

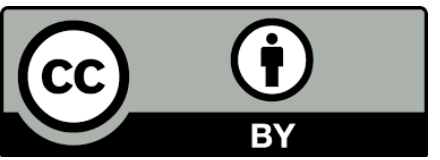

(C) 2021 by the author. This is an open access article distributed under the conditions of the Creative Commons by Attribution License, which permits unrestricted use, distribution, and reproduction in any medium or format, provided the original work is correctly cited. 
tissues were analyzed. The greenhouse results revealed that the growth parameters of $C$. colocynthis in the experimental treatments were significantly $(p \leq 0.05)$ lower than those in agricultural soil. The growth of $C$. colocynthis significantly $(p \leq 0.05)$ decreased as the ratio of powdered marble increased. The greatest increase in plant biomass was observed in the $M T P M_{25}$, followed by $M_{T P M}$ and $M_{5 T P}$ 75. Some phytotoxic effects on plants were observed in MPTM75. The concentrations of $\mathrm{Zn}, \mathrm{Cu}, \mathrm{Pb}$, and $\mathrm{Cd}$ in $\mathrm{C}$. colocynthis roots were significantly ( $p \leq 0.05$ ) higher than those of shoots, with maximum values of $112.98 \mathrm{mg} \mathrm{kg}^{-1}$, $201.3 \mathrm{mg} \mathrm{kg}^{-1}, 201.2 \mathrm{mg} \mathrm{kg}^{-1}$, and $40.03 \mathrm{mg} \mathrm{kg}^{-1}$, respectively. This is a typical characteristic of accumulator plants and maybe one of the tolerance mechanisms. Plants in the experimental treatments were characterized by $\mathrm{TF}<1$ and $\mathrm{BCF}<1$, which indicate that $C$. colocynthis could be useful for phytostabilization strategies. Our study demonstrates that the phytostabilization by $C$. colocynthis assisted by powdered marble could represent a successful and environmentally friendly strategy to remediate acidic polymetallic sites.

\section{Keywords}

Acidic mine tailings; heavy metals; assisted phytostabilization; C. colocynthis; marble waste; remediation

\section{Introduction}

Mining is a globally important economic activity that provides the raw materials for several essential human activities [1]. However, mining is a high-risk activity, not only for the workers (miners, engineers, etc.) associated with this industry but also for the local population and the environment surrounding the mining areas [2]. Tailings are the most environmentally damaging residue from mining activities. Tailings are a by-product of no commercial value, which are generated in huge volumes and stored untreated in the open air [3]. Mine tailings usually contain high levels of heavy metals, have low nutritional value, and are subject to erosion, especially in arid and semi-arid environments. They persist in the environment, contaminate the food chain, and cause various health problems [4].

Sustainable remediation of mine tailings can be difficult to implement due to the high cost of current remediation techniques. Several physical, chemical, and biological methods have been proposed to remediate mine tailings. These include leaching or washing, chemical stabilization with mineral and organic amendments, alkaline hydrolysis, photolysis, bioremediation, and phytoremediation [4-6]. Phytoremediation is a promising and highly researched methodology for the improvement of polymetallic contaminated soils [7]. Several mechanisms of phytoremediation have been identified, such as phytoextraction, phytodegradation, rhizofiltration, and phytostabilization [8]. The most viable phytoremediation mechanism for a particular situation will depend on the physiology of the plant species, the response of the plant species to the treatments, the specific heavy metals, soil structure, and microorganisms [8].

Assisted phytostabilization is a profitable technique that uses plants to reduce the mobility of metallic trace elements (MTEs) and their transfer to the surrounding environment $[9,10]$. The key element of a successful phytostabilization program is the optimal choice of the plant species [11]. 
Metallophytes are generally considered the best candidates because they are well adapted to the environmental conditions of the target site, better in terms of survival, and are characterized by high tolerance to hotspot contamination [12]. Due to their specific genetic and morphological characteristics, metallophytes can develop a biological mechanism to survive and reproduce on polymetallic soils without being affected by the high concentrations of metals.

The native plant used in this study is Citrullus colocynthis (L.) Schrader. This species was selected following a meticulous botanical survey on polymetallic mining sites [13]. C. colocynthis is a perennial metallophyte with an enhanced ability to survive in xeric and contaminated soils. This plant can accumulate a significant metal load in its tissue and can be easily manipulated in laboratory conditions. C. colocynthis grows rapidly, has a short vegetative cycle, and readily produces seeds. It can also be used in several pharmacological activities and medical applications [14]. Most research on $C$. colocynthis has focused on its chemical constituents [15], antioxidant properties [16], anti-inflammatory activity [17], and pharmacological effects [18]. Its potential use as a metal-accumulator plant and its effectiveness in the phytostabilization of contaminated soils has been relatively less well-studied.

Combining the use of soil amendments (chemical immobilization) with plant cover as part of an assisted phytostabilization regime will lead to more effective remediation [19]. Immobilization techniques often use inorganic amendments to facilitate the removal of metals from the soil solution through adsorption, complexation, or precipitation reactions, thereby making the metals unavailable for uptake by humans or plants and preventing their leaching into groundwater [20]. One such inorganic amendment is marble waste. Marble waste is rich in carbonates, which strongly influence the soil $\mathrm{pH}$, as well as the accumulation and mobility of metals. Several studies have proven its efficiency in the restoration of contaminated soils [19, 21-25]. The use of marble waste is commonly used for phytoremediation, and especially phytostabilization.

The current study aims to propose sustainable solutions for the remediation of polymetallic abandoned mine sites using assisted phytostabilization by $C$. colocynthis and marble waste. Their effects on the neutralization of soil acidity and the uptake of metals were evaluated.

\section{Materials and Methods}

\subsection{Soil Sampling and Characterization}

Mine tailings, an acidic polymetallic waste, were directly collected $(15-25 \mathrm{~cm}$ in depth) from the residues of an abandoned mine site located approximately $35 \mathrm{~km}$ northwest of Marrakech, in the Jebilet Mountains (Figure 1). The powdered marble was recovered from a processing unit and used in the experiment without any prior treatment. An agricultural soil (clean soil) was collected from a 0-10-cm-deep layer in the garden of Cadi Ayyad University (Marrakech-Morocco) and used as a reference. The soil had not received manure or pesticide applications. 


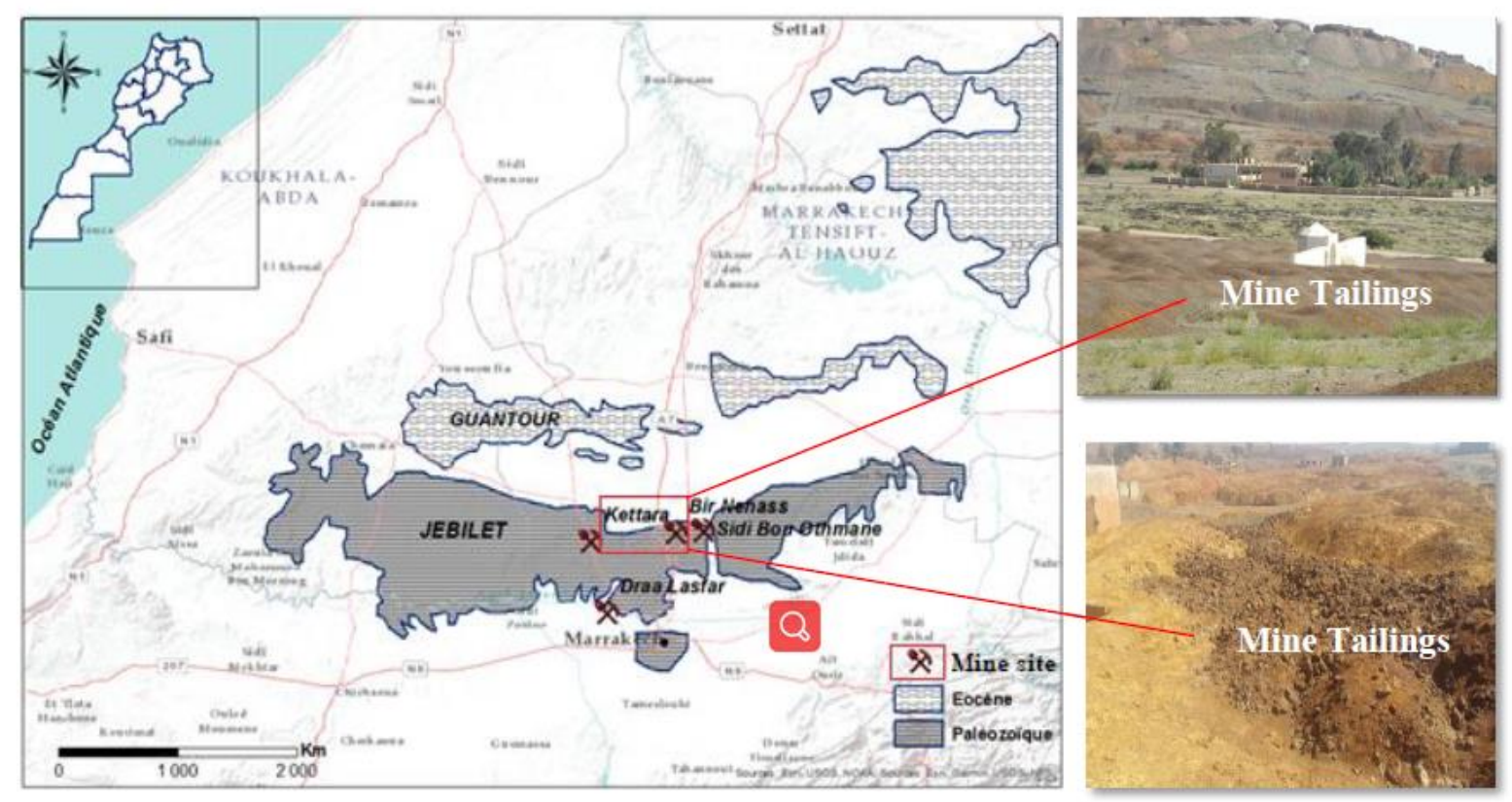

Figure 1 Location of the abandoned mine site [13].

The soil samples were air-dried in ambient conditions and passed through a 2-mm mesh sieve. The physical and chemical properties of the soil were determined according to the standard procedures published in the Official Methods of Soil Analysis [26]. The soil texture was determined using the Robinson pipette method combined with sieving. The calcium carbonate $\left(\mathrm{CaCO}_{3}\right)$ equivalent was determined using a Bernard calcimeter. Electrical conductivity (1:5 w/v soil water suspensions) and $\mathrm{pH}$ (1:2.5 w/v soil water) were measured using a multiparameter probe-type LF 92 WTW. Total organic carbon was determined by the oxidation of the organic matter using potassium dichromate [27], available $\mathrm{P}\left(\mathrm{P}_{2} \mathrm{O}_{5}\right)$ by the Olsen method [28], and total Kjeldahl nitrogen was determined using the Kjeldahl method [29].

Analyses of major and trace elements were conducted by X-ray fluorescence spectrometry (Olympus, UK) and atomic absorption spectrophotometer (AAS) (Shimadzu AA-6300), respectively. Heavy metal concentrations were determined after the complete digestion of a $0.50 \mathrm{~g}$ dry sample of mine tailings at $500^{\circ} \mathrm{C}$. The sample was digested in $7 \mathrm{~mL}$ nitric acid $\left(\mathrm{HNO}_{3}\right)(65 \% \mathrm{w} / \mathrm{w}), 2 \mathrm{~mL}$ hydrofluoric acid (HF) $(40 \% \mathrm{w} / \mathrm{w})$, and $1 \mathrm{~mL}$ perchloric acid $\left(\mathrm{HClO}_{4}\right)(60 \% \mathrm{w} / \mathrm{w})$ in a Teflon beaker. The sample solutions were filtered using a $0.45 \mathrm{~mm}$ cellulose nitrate filter, and the volume was adjusted to $10 \mathrm{~mL}$ with $0.1 \mathrm{M} \mathrm{HNO}_{3}$. The total metal concentrations were analyzed in triplicate and calculated on a dry weight basis $\left(\mathrm{mg} \mathrm{kg}^{-1} \mathrm{dw}\right)$. The physical and mineral properties of powdered marble were determined using the methods outlined in $[25,30]$.

\subsection{Plant Species}

\subsubsection{Botanical Description}

The native Moroccan plant Citrullus colocynthis (L.) Schrader was used in this study (Figure 2). C. colocynthis is a creeping, herbaceous perennial plant bristling with hair (Table 1). The plant has rough, angular stems with tendrils and large, alternate, deeply cut leaves. It is characterized by a 
stout, perennial, long taproot, with occasional rooting at the nodes on thick branches. Yellow flowers with five somewhat welded petals appear in the axils of the leaves in summer.

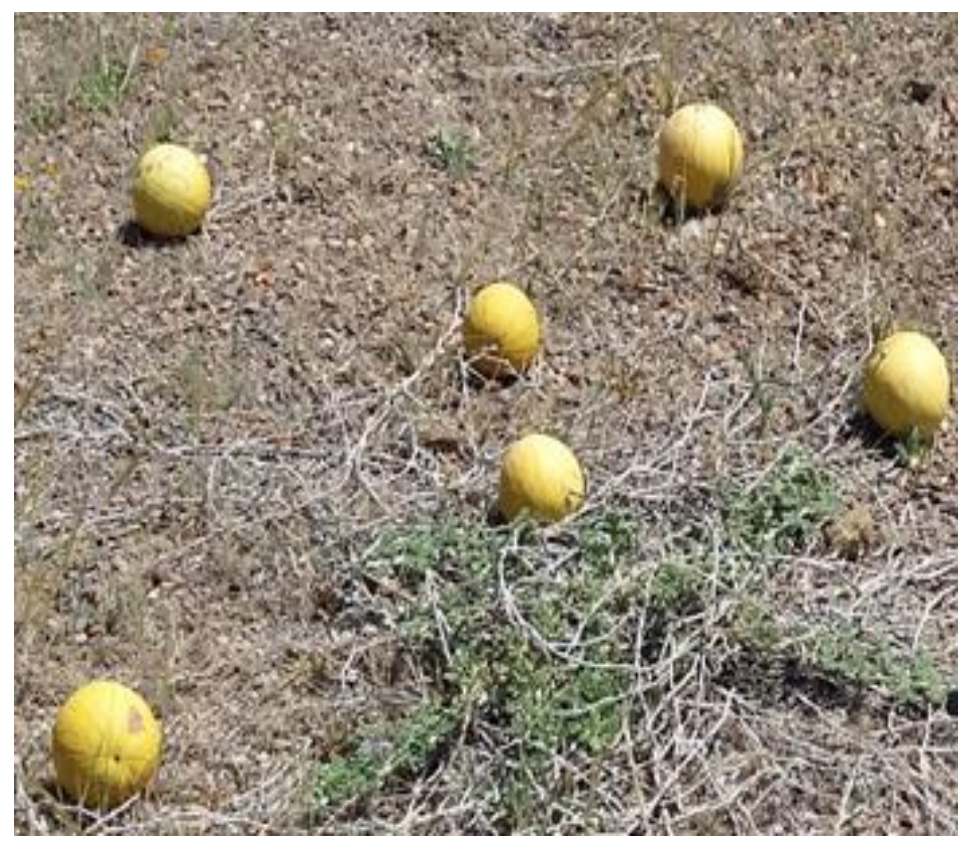

Figure 2 Citrullus colocynthis (L.) Schrader.

Table 1 Intrinsic characteristics of Citrullus colocynthis (L.).

\begin{tabular}{ll}
\hline Family & Cucurbitaceae \\
Common name & Coloquinte \\
Life cycle & Perennial \\
Stem Height & A creeping stem that can reach $3 \mathrm{~m}$ \\
Root system & Pivoting \\
Cotyledon type & Dicotyledons \\
Bioclimate conditions & Arid and semi-arid areas \\
\hline
\end{tabular}

The spherical fruits measure 5 to $10 \mathrm{~cm}$ in diameter with a fleshy pulp. The young fruits are green and light-yellow, becoming completely yellow when ripe. Dry fruits can remain on the plant for a long time. The light, spongy, orange-yellow flesh is very bitter and toxic. The numerous edible seeds are ovoid and flattened, varying in color from orange to blackish brown. The fruit's bitter taste is due to the chemicals colocynthin and colocynthetin. C. colocynthis is a widespread species in arid and Saharan climate regions and has a wide range of pharmacological properties that promote its use in several medical applications [14].

\subsubsection{Seed Sampling, Treatment, and Germination}

C. colocynthis seeds were collected in 2018 from an abandoned mining area located about 33 $\mathrm{km}$ from Marrakech City. This region is characterized by a Mediterranean climate (arid to semi-arid bioclimate) with a low and irregular annual rainfall of approximately $300 \mathrm{~mm}$ and a mean temperature of $11.5^{\circ} \mathrm{C}$ in January and $36.8^{\circ} \mathrm{C}$ in July (ONEM, 1997). In the laboratory, healthy 
seeds were separated from infertile seeds and disinfected with sodium hypochlorite $5 \%(\mathrm{NaClO})$ for $10 \mathrm{~min}$ and then rinsed thrice with distilled water. The seeds were mechanically scarified and soaked in $200 \mathrm{~mL}$ of water at room temperature for $24 \mathrm{~h}$ to break seed dormancy. Then, the seeds were directly sown into pots. During the experiment, germination percentage, germination rate, germination index, and germination stress were controlled and reported.

\subsection{Greenhouse Experiment}

Growth experiment treatments (Figure 3a) were conducted to test the growth of $C$. colocynthis in mine tailing amended with powdered marble. A total of $3 \mathrm{~kg}$ of materials (Mine tailing + powdered marble) at predetermined proportions (Table 2) were thoroughly mixed and placed in the pots. Each treatment was prepared in triplicate. Each pot was sown with five $C$. colocynthis seeds (Figure $3 \mathrm{~b}$ ) and allowed to grow for 4 months from $1^{\text {st }}$ April to $30^{\text {th }}$ July under semicontrolled greenhouse conditions.

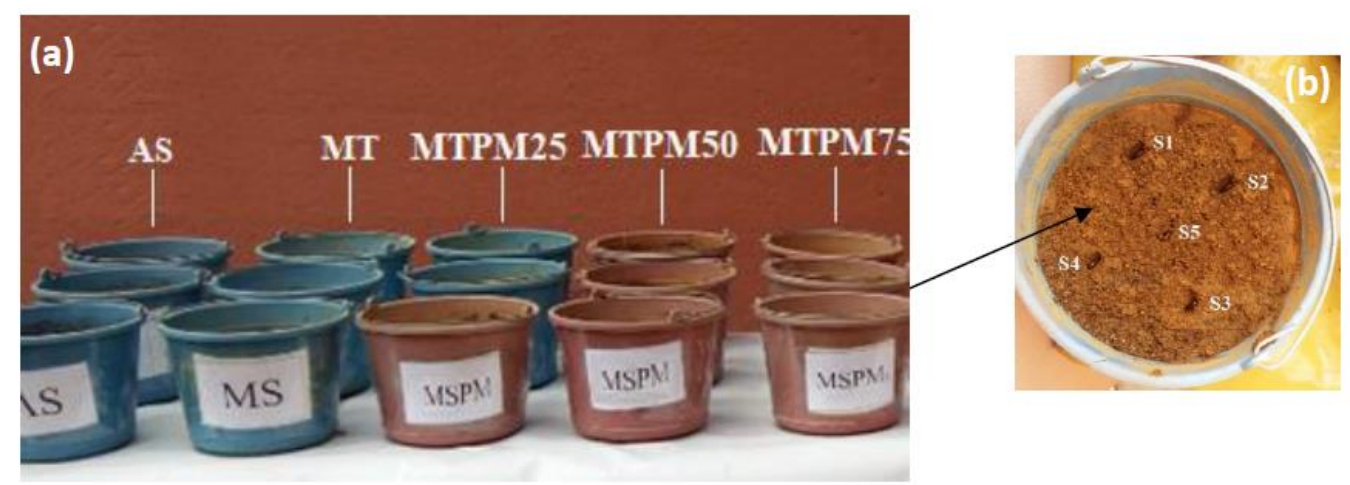

Figure 3 Growth experimental treatments (a) and sowing seeds (b) of C. Colocynthis (S1-S5: seeds).

Table 2 Proportions of the experimental materials.

\begin{tabular}{ll}
\hline Experimental treatments & Total of 3 kg per pot $(w / w)$ \\
\hline AS & Agricultural Soil \\
MT & $100 \%$ Mine Tailings \\
MTPM $_{25}$ & $75 \%$ Mine Tailings $+25 \%$ Powdered Marble \\
MTPM $_{50}$ & $50 \%$ Mine Tailings $+50 \%$ Powdered Marble \\
MTPM $_{75}$ & $25 \%$ Mine Tailings $+75 \%$ Powdered Marble \\
\hline
\end{tabular}

\subsection{Analysis of Plant Material}

\subsubsection{Physiological Parameters}

Four months after planting the seeds, seedlings were removed from the soil. They were washed three times with tap water and then with distilled water to remove all visible soil particles. The 
length and the fresh and dry weights of the plant tissues in each treatment were measured as follows:

Plant length (PL): Shoot and root lengths of the plants were measured manually using a graduated ruler.

Fresh material (FM): Immediately after cutting, the weight of the roots and aerial parts were weighed using a precision balance.

Dry material (DM): The weight of both the roots and aerial parts were weighed using a precision balance after drying them in an oven at $70^{\circ} \mathrm{C}$ for $48 \mathrm{~h}$.

\subsubsection{Heavy Metal Analysis}

The dried biomass was grounded to a powder in a porcelain mortar and sieved to obtain a size of less than $2 \mathrm{~mm}$. About 1-2 $\mathrm{g}$ of plant tissue was burnt to ash in a muffle furnace at $450^{\circ} \mathrm{C}$ for $4 \mathrm{~h}$ and digested in an aqua regia solution (a 1:3 mixture of nitric acid $\left[\mathrm{HNO}_{3}\right.$ ] concentrated with hydrochloric acid [HCl]) overnight at room temperature. The mixture was then boiled for $2 \mathrm{~h}$, according to the standard method NF ISO 11466 (AFNOR, 1995). After cooling, the digested samples were filtered through a $0.45 \mathrm{~mm}$ cellulose nitrate filter and adjusted to a volume of $10 \mathrm{~mL}$ with $0.1 \mathrm{M} \mathrm{HNO}_{3}$. The concentrations of total metals in the shoots, stems, and roots were determined by Atomic Absorption Spectrophotometer AAS (Shimadzu AA-6300).

\subsection{Data Analysis}

The translocation factor (TF) indicates the efficiency of the plant in translocating the accumulated metals from its roots to shoots. It is calculated as follows [4, 31]:

$$
T F=[\text { Metal }]_{\text {shoot }} /[\text { Metal }]_{\text {root }}
$$

The bioconcentration factor (BCF) indicates the efficiency of a plant species in accumulating a metal into its tissues from the surrounding environment. It is calculated as follows [4, 32]:

$$
B C F=[\text { Metal }]_{\text {harvested tissue }} /[\text { Metal }]_{\text {soil }}
$$

The data of the different treatments were analyzed by calculating the mean values and standard deviation. The differences between the means of the groups were evaluated using analysis of variance (ANOVA) followed by pairwise comparisons using the Student-Newman-Keuls test as appropriate. P-values of $<0.05$ indicated statistically significant differences. All the statistical evaluations were performed using the SPSS software (Statistical Package for Social Sciences) (IBM SPSS Statistics 21.0 software, IBM, Chicago, IL, USA).

\section{Results and Discussion}

\subsection{Physicochemical Properties of Materials}

The major physicochemical properties of the experimental materials are presented (Table 3). The mine tailings were highly acidic, with a pH of around $2.61 \pm 0.09$ and high conductivity of 1384 $\pm 1.71 \mathrm{mS} \mathrm{m}^{-1}$. These residues had relatively low levels of $\mathrm{C}, \mathrm{P}$, and $\mathrm{N}$, which effectively promote 
plant growth and development. Soils with these properties are unsuitable for the establishment of plant cover.

Table 3 General properties of experimental materials.

\begin{tabular}{lllll}
\hline Element & Unit & $\mathrm{MT}$ & $\mathrm{PM}$ & $\mathrm{AS}$ \\
\hline $\mathrm{pH}$ & --- & $2.61 \pm 0.09$ & $8.95 \pm 0.05$ & $7.21 \pm 0.06$ \\
$\mathrm{EC}$ & $\mathrm{mS} \mathrm{m}^{-1}$ & $1384 \pm 101.2$ & $128 \pm 1.30$ & $369 \pm 1.56$ \\
$\mathrm{CaCO}_{3}$ & $\%$ & $4.60 \pm 0.33$ & $92.11 \pm 1.08$ & $5.03 \pm 0.45$ \\
$\mathrm{~N}$ & $\mathrm{~g} \mathrm{~kg}^{-1}$ & $0.3 \pm 0.05$ & $1.7 \pm 0.07$ & $12 \pm 1.05$ \\
$\mathrm{C}$ & $\mathrm{g} \mathrm{kg}^{-1}$ & $3.5 \pm 0.21$ & --- & $229 \pm 2.04$ \\
$\mathbf{P}$ & $\mathrm{mg} \mathrm{kg}^{-1}$ & $1197 \pm 12.01$ & $490 \pm 6.02$ & $1185 \pm 10.09$ \\
$\mathrm{~K}$ & $\mathrm{mg} \mathrm{kg}^{-1}$ & $96.4 \pm 0.96$ & $990 \pm 7.21$ & $2560 \pm 13.06$ \\
$\mathrm{Na}$ & $\mathrm{mg} \mathrm{kg}^{-1}$ & $8.40 \pm 0.08$ & $1536 \pm 9.32$ & $93 \pm 1.04$ \\
$\mathrm{~S}$ & $\mathrm{~g} \mathrm{~kg}^{-1}$ & $1.25 \pm 1.06$ & $0.38 \pm 0.03$ & $0.56 \pm 0.03$ \\
$\mathrm{Fe}$ & $\mathrm{g} \mathrm{kg}^{-1}$ & $23.39 \pm 2.72$ & $6.76 \pm 1.02$ & $20.2 \pm 0.09$ \\
$\mathrm{Cu}$ & $\mathrm{mg} \mathrm{kg}^{-1}$ & $1670 \pm 12.17$ & $16 \pm 7.02$ & $91 \pm 4.12$ \\
$\mathrm{Zn}$ & $\mathrm{mg} \mathrm{kg}^{-1}$ & $610 \pm 4.36$ & $20 \pm 0.08$ & $100 \pm 1.22$ \\
$\mathrm{~Pb}$ & $\mathrm{mg} \mathrm{kg}^{-1}$ & $560 \pm 15.72$ & --- & $73 \pm 6.01$ \\
$\mathrm{Cd}$ & $\mathrm{mg} \mathrm{kg}^{-1}$ & $78.41 \pm 0.88$ & ---- & --- \\
\hline
\end{tabular}

The presence of toxic levels of metallic trace elements in the soil may also significantly affect plant growth. Mine tailing samples were characterized by high levels of $\mathrm{Cu}, \mathrm{Zn}, \mathrm{Pb}$, and $\mathrm{Cd}$, which exceeded the limits established by the European Directive 86/278/EEC (Council of the European Communities Directive (86/278/EEC) 1986) on the protection of the environment. Therefore, they pose a potentially serious risk for the environment and public health.

Powdered marble had an alkaline $\mathrm{pH}$ of 8.95 , a high content of carbonates $\left(\mathrm{CaCO}_{3}\right)$, and low contents of metallic trace elements (Table 3 ). The high carbonate content plays a key role in the $\mathrm{pH}$ variation and gives the amendment strong acid-neutralizing properties. The agricultural soil had a neutral $\mathrm{pH}(7.21 \pm 0.06), \mathrm{EC} \leq 369 \mathrm{mS} \mathrm{m}^{-1}$, and low concentrations of metallic trace elements that did not exceed the AFNOR reference values (NFU44-041, 1985). In contrast, powdered marble was rich in essential elements, which are important for plant growth.

\subsection{Effect of Powdered Marble on pH, EC, and MTEs Content}

The results of $\mathrm{pH}, \mathrm{EC}$, and MTEs concentrations in the experimental treatments are presented in Table 4. 
Table $4 \mathrm{pH}$ and MTEs contents of mine tailings mixed with different proportions of powdered marble.

\begin{tabular}{llllll}
\hline Element & Unit & MT & MTPM $_{25}$ & MTPM $_{50}$ & MTPM75 $^{\text {a }}$ \\
\hline $\mathrm{pH}$ & --- & $2.61 \pm 0.09^{\mathrm{c}}$ & $7.1 \pm 0.1^{\mathrm{b}}$ & $7.2 \pm 0.2^{\mathrm{b}}$ & $7.97 \pm 0.1^{\mathrm{a}}$ \\
$\mathrm{EC}$ & $\mathrm{mS} \mathrm{m}^{-1}$ & $1384 \pm 101.2^{\mathrm{a}}$ & $483 \pm 0.6^{\mathrm{b}}$ & $457 \pm 2.5^{\mathrm{b}}$ & $439 \pm 1.6^{\mathrm{b}}$ \\
$\mathrm{Cu}$ & $\mathrm{mg} \mathrm{kg}^{-1}$ & $1670 \pm 12.17^{\mathrm{a}}$ & $1381 \pm 6.08^{\mathrm{b}}$ & $1186 \pm 7.81^{\mathrm{c}}$ & $1106 \pm 8.72^{\mathrm{d}}$ \\
$\mathrm{Zn}$ & $\mathrm{mg} \mathrm{kg}^{-1}$ & $610 \pm 4.36^{\mathrm{a}}$ & $350 \pm 0.89^{\mathrm{b}}$ & $240 \pm 13.11^{\mathrm{c}}$ & $130 \pm 13.11^{\mathrm{d}}$ \\
$\mathrm{Pb}$ & $\mathrm{mg} \mathrm{kg}^{-1}$ & $560 \pm 15.72^{\mathrm{a}}$ & $388.22 \pm 12.9^{\mathrm{b}}$ & $190 \pm 14^{\mathrm{c}}$ & $68.50 \pm 3.70^{\mathrm{d}}$ \\
$\mathrm{Cd}$ & $\mathrm{mg} \mathrm{kg}^{-1}$ & $78,41 \pm 2.57^{\mathrm{a}}$ & $75.18 \pm 0.88^{\mathrm{a}}$ & $60.01 \pm 2.86^{\mathrm{b}}$ & $33.50 \pm 1.35^{\mathrm{c}}$ \\
\hline
\end{tabular}

Results are expressed in $\mathrm{mg} \mathrm{kg}^{-1}$ of M.S. \pm ES. Different letters (a-d) indicate significant differences between the studied treatments (Student-Newman-Keuls test, $p \leq 0.05, n=3$ ).

The $\mathrm{pH}$ values increased from 2.61 in $\mathrm{MT}$ to 7.1, 7.2, and 7.97 in treatments amended with powdered marble MTPM 25, MTPM $_{50}$, and MTPM $_{75}$, respectively (Table 4). In contrast, the EC value decreased from $1384 \mathrm{mS} \mathrm{m}^{-1}$ in MT to 483, 457, and $439 \mathrm{mS} \mathrm{m}^{-1}$ in MTPM $25, M_{T P M}$ and MTPM75, respectively (Table 4 ). When moist mine tailings are exposed to air, the oxidation and hydrolysis mechanisms of sulfides are activated, resulting in the formation of sulfuric acid. Therefore, the $\mathrm{pH}$ values and the solubility of the MTEs increase [33-35]. The application of powdered marble to mine tailings rich in mineral sulfides causes an increase in the $\mathrm{pH}$ and a decrease in the EC of the soil.

The concentrations of $\mathrm{Cu}, \mathrm{Zn}, \mathrm{Pb}$, and $\mathrm{Cd}$ in the mine tailings were high (Table 4). After the application of powdered marble, the concentrations of these elements decreased. The addition of powdered marble significantly ( $p \leq 0.05$ ) decreased the concentrations of metals in soil, suggesting that the carbonates played an active role in reducing the solubility of metals; thereby, greatly decreasing the spread of metals in the environment. The carbonate materials, which constitute a major part of powdered marble, can reduce metal solubility by the formation of stable metal chelates $[24,36]$.

\subsection{Effect of Powdered Marble on Seed Germination and Plant Growth}

No $C$. colocynthis seeds germinated in mine tailings (MT) (Figure 4). This result was expected due to the high acidity and the high metal content in these residues (Table 4). In contrast, maximum germination rates were observed in the agricultural soil. One week after seed sowing, germination rates in treatments amended with powdered marble MTPM 25, MTPM$_{50}$, and MTPM75 were increased (Figure 4). Delayed germination was understandable as dormancy persisted in $C$. colocynthis seeds. Changes in seedling height $(\mathrm{cm})$ of $C$. colocynthis were affected by different proportions of powdered marble. 


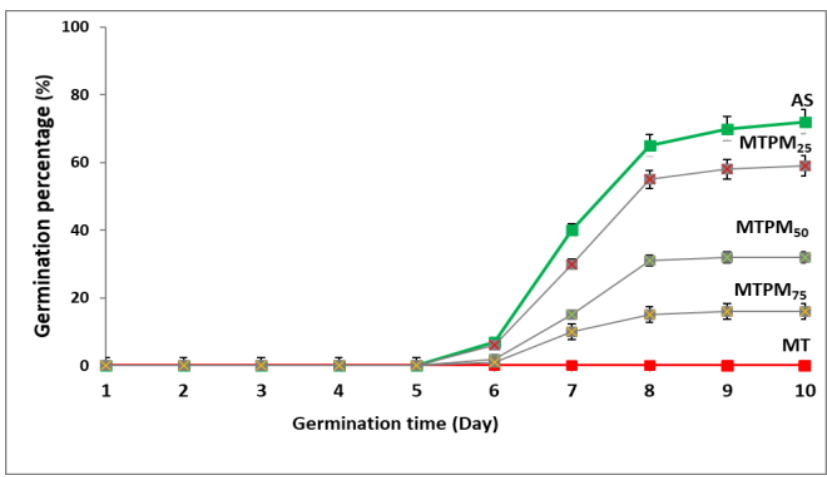

Figure 4 Germination (\%) of $C$. colocynthis seeds in the experimental treatments.

Regarding the results obtained from the amended treatments, the highest increase in plant biomass was observed in treatment MTPM $_{25}$, followed by treatment MTPM$_{50}$ and treatment MTPM $_{75}$ (Figures $5 a$ and 5b). Some phytotoxic effects such as stunting, curling of young shoots, death of leaf tip, chlorosis, and inhibition of root growth were observed on plants when using $75 \%$ of powdered marble, possibly due to the compact texture and high level of soluble salts in this treatment. The application of powdered marble significantly $(p \leq 0.05)$ enhanced the seed germination rate of $C$. colocynthis and could be used as an amendment in low concentrations (25\%).

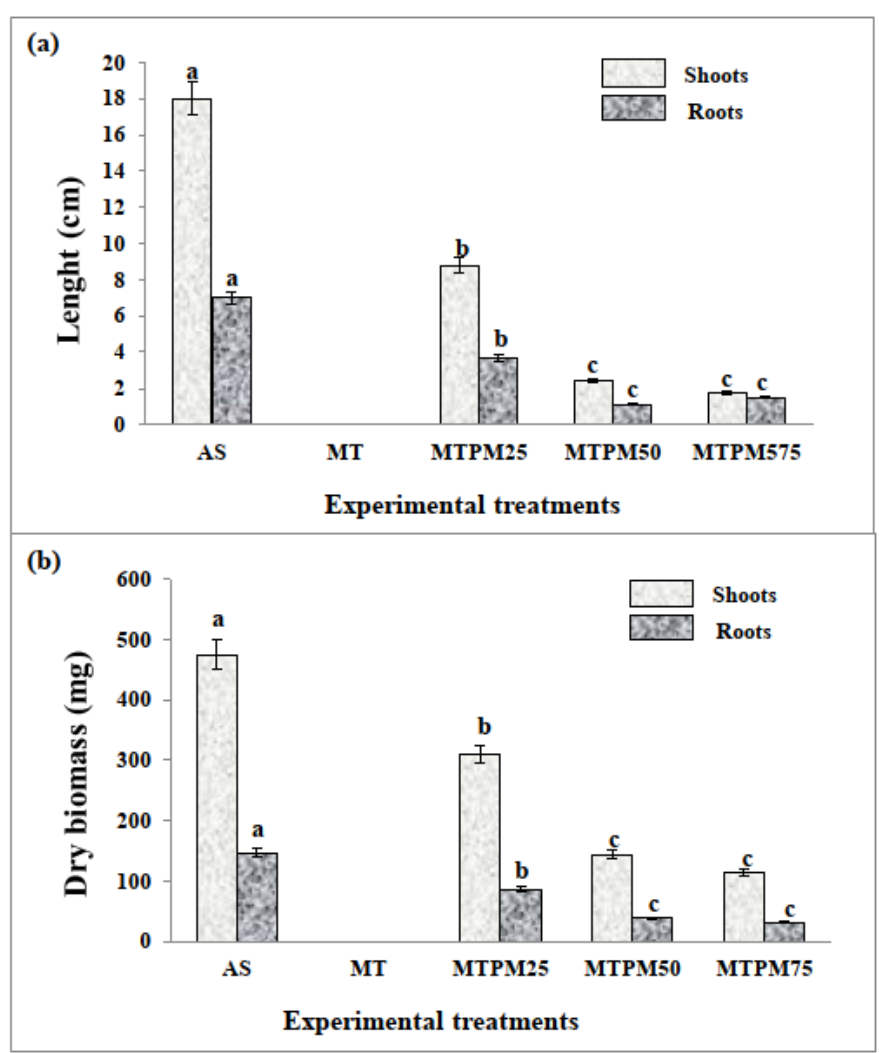

Figure 5 Length (a) and dry biomass (b) of the shoots and roots of $C$. colocynthis at the end of the experiment in the experimental treatments. Different letters $(a-c)$ denote statistically significant differences (Student-Newman-Keuls test, $p \leq 0.05$ ) between the investigated treatments. 
In the treatments using powdered marble, $C$. colocynthis plants were able to grow, although the weight of dry biomass, the length of the leaves, and roots were significantly $(p \leq 0.05)$ lower than those recorded in plants grown in the agricultural soil (Figure 5a and Figure 5b). The capacity of agricultural soil to supply the essential macronutrients $(N, P, K)$ could explain the different relative growth of the plants. The lack of essential elements could be the major cause of limited plant growth in the amended treatments. Therefore, fertilizer amendment should be supplemented to the powdered marble, as it is recommended in most soil rehabilitation projects $[24,37]$.

\subsection{Effects of Powdered Marble on Metal Accumulation in Plants}

In C. colocynthis plants growing in the treatments MTPM $_{25}, M_{T P M}$, and MTPM 75 , the concentrations of MTEs ( $\mathrm{Zn}, \mathrm{Cu}, \mathrm{Pb}$, and $\mathrm{Cd})$ were significantly higher $(\mathrm{p} \leq 0.05)$ than those growing in agricultural soil (Figure 6). The highest levels of MTEs in plant tissues were obtained in the treatment MTPM $_{25}$, followed by the treatments MTPM $_{50}$ and MTPM $_{75}$ (Figure 6). The application of powdered marble significantly $(p \leq 0.05)$ limited the accumulation of MTEs by $C$. colocynthis tissues. The increase in soil $\mathrm{pH}$ resulted in a significant decrease in metal content in the shoots and roots. Some physical and chemical processes, including precipitation, absorption, complexation, redox reaction, and ion exchange, occur with changes in soil $\mathrm{pH}$, which can influence the uptake of metals from soil; thus, reducing their uptake by plants at a higher soil pH [14, 21-23].
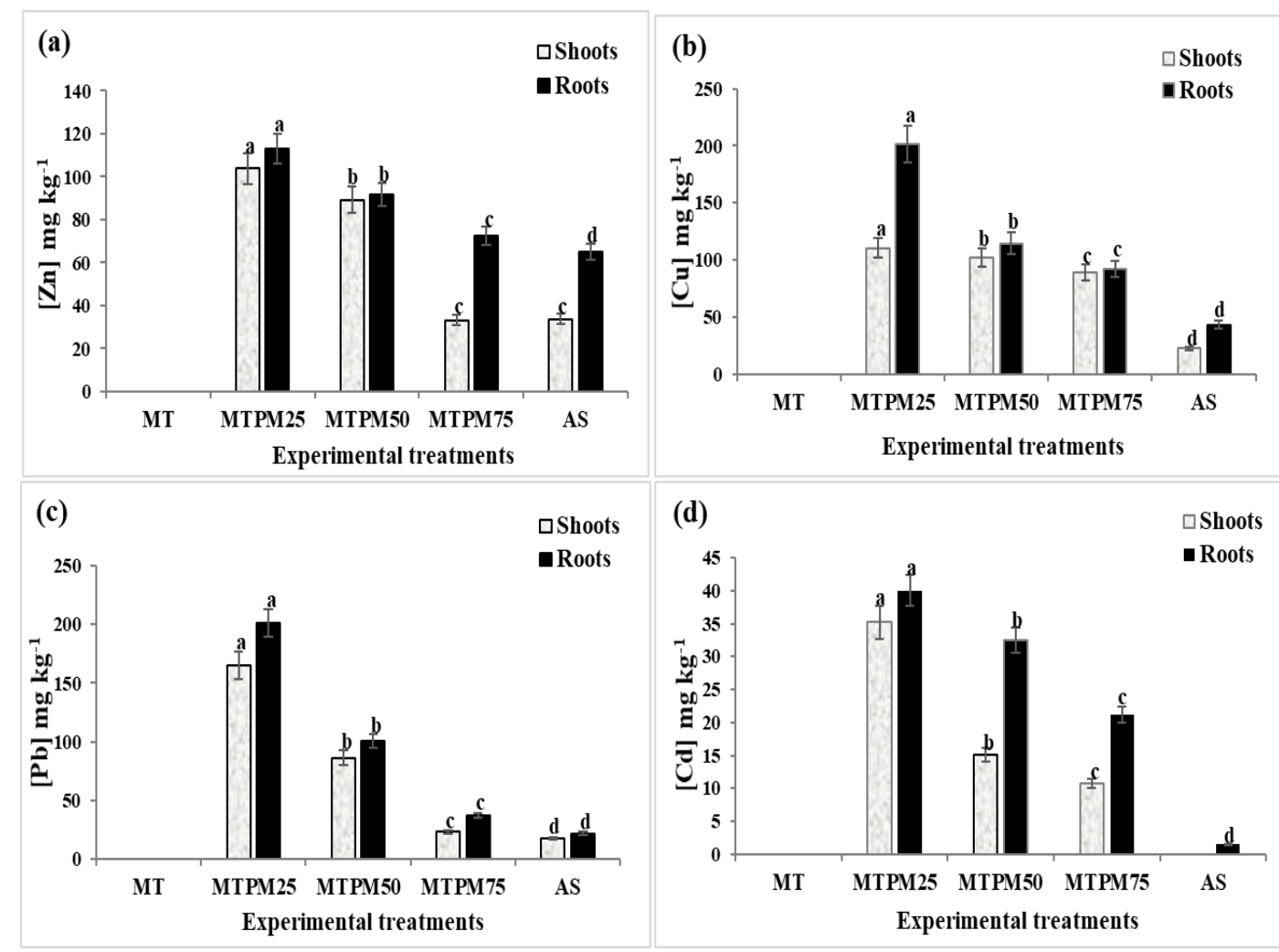

Figure 6 The concentrations of $\mathrm{Zn} \mathrm{(a),} \mathrm{Cu}(\mathrm{b}), \mathrm{Pb}(\mathrm{c})$, and $\mathrm{Cd}(\mathrm{d})$ (mean \pm standard deviation) of the leaves and roots of $C$. colocynthis in the experimental treatments. Different letters (a-d) indicate significant differences between the studied treatments (Student-Newman-Keuls test, $p \leq 0.05, n=3$ ). 
The metal concentrations in $C$. colocynthis plants were higher than those obtained in plants growing in natural soil estimated by Kramer [38] (Zn: $100-300 \mathrm{mg} \mathrm{kg}^{-1}, \mathrm{~Pb}: 0.6-28 \mathrm{mg} \mathrm{kg}^{-1}, \mathrm{Cu}: 20-$ $30 \mathrm{mg} \mathrm{kg}^{-1}$, and $\mathrm{Cd}: 0.1-3 \mathrm{mg} \mathrm{kg}^{-1} \mathrm{dry}$ weight). C. colocynthis plants can tolerate and accumulate significant concentrations of MTEs in their tissues. The concentrations of MTEs in roots were significantly $(p \leq 0.05)$ higher than those in shoots ([Shoots] $<[$ Roots]) (Figure 6$)$. This physiological trait is a tolerance mechanism in accumulator plants [39]. C. colocynthis is a good candidate for use in the stabilization of acidic polymetallic soils due to its high tolerance and strong accumulation of MTEs in roots. However, it cannot be classified as a hyperaccumulator of MTEs and is therefore suitable for the phytostabilization of soils contaminated with MTEs $(\mathrm{Cu}, \mathrm{Zn}, \mathrm{Pb}$, and Cd) [40]. Metal concentrations were below the levels stipulated by the US Domestic Animal Metal Toxicity limits [41], which confirms that C. colocynthis is a good candidate for phytostabilization and could be used safely without detriment to grazing animals.

\subsection{Efficiency of Phytoremediation}

Bioconcentration factor (BCF) and translocation factor (TF) were used to assess the accumulation efficiency of $C$. colocynthis, as well as to estimate their phytoremediation potential (phytostabilization and/or phytoextraction) [4].

The experimental treatments of $C$. colocynthis were characterized by TF $<1.0$ (Figure 7a). A TF of $<1.0$ indicates that the plants can accumulate metals in their roots and limit the translocation of metals to the shoots. This reduces the mobility of metals and their leaching into groundwater. The plants minimize the transfer of metals into the food chain, ultimately improving human health.

C. colocynthis is characterized by excluder traits and can be used successfully in phytostabilization [42]. Similar results were observed for other plant species (Medicago sativa L., Zygophyllum fabago, Helichrysum decumbens, Erica andevalensis, Tamarix sp., Lygeum spartum, Cistus, Cytisus...) in mining areas [25, 43-45]. The mobility of MTEs into $C$. colocynthis tissues from mine tailings was evaluated through the determination of the BCF (Figure 7b). The BCF values of $\mathrm{Cu}, \mathrm{Zn}$, and $\mathrm{Pb}$ in $\mathrm{C}$. colocynthis plants under different treatments were significantly $(\mathrm{P} \leq 0.05)$ lower than 1 $(\mathrm{BCF}<1)$, except for $\mathrm{Cd}$, indicating its lower accumulation of metals in tissues and can be considered as a metal excluder species growing on mine tailings. 
(a)
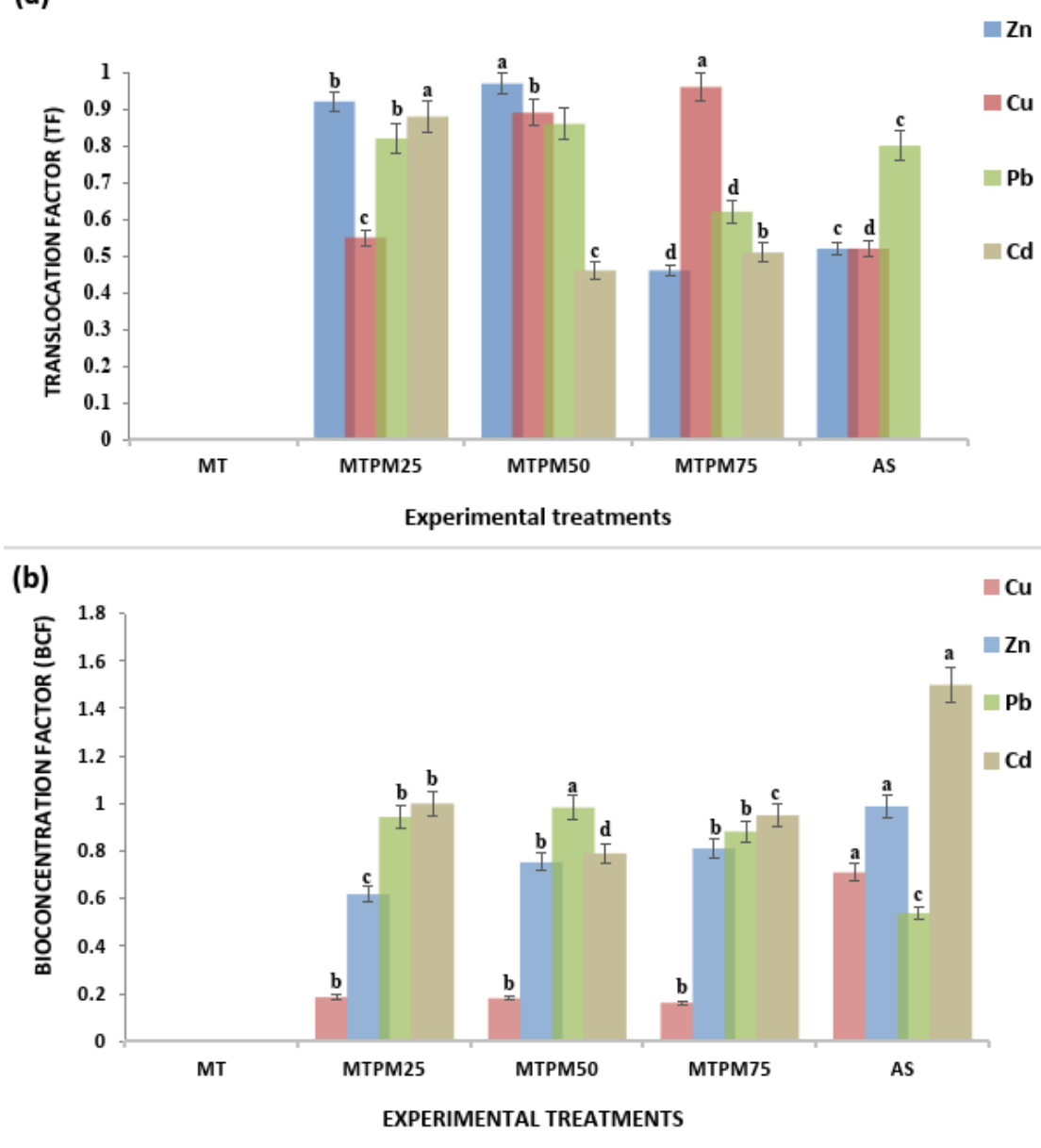

Figure 7 Translocation and bioconcentration factors of $\mathrm{Cu}, \mathrm{Zn}, \mathrm{Pb}$, and $\mathrm{Cd}$ in $\mathrm{C}$. colocynthis plants under the experimental treatments. Different letters (a-d) indicate significant differences between the different treatments studied (Student-NewmanKeuls test, $p \leq 0.05, n=3$ ).

In general, plants exhibiting $\mathrm{TF}<1$ and $\mathrm{BCF}<1$ are suitable for MTEs phytostabilization programs $[4,39,46,47]$, as these low values indicate that a given species is unable to extract large amounts of metal from the soil and translocate it to the shoots.

\section{Conclusions}

This study demonstrated that powdered marble can be successfully used in the remediation of a highly acidic polymetallic contaminated soil, correcting soil acidity and reducing the uptake of metals, which facilitates the establishment of $C$. colocynthis. The best plant growth was obtained in $\mathrm{MTPM}_{25}$, with $25 \%$ of $\mathrm{CaCO}_{3}$ as the liming material. The application of powdered marble led to a decrease in the uptake of $\mathrm{Cu}, \mathrm{Pb}$, and $\mathrm{Zn}$, probably as a result of increased soil $\mathrm{pH}$. This could be explained by the formation of metal carbonates, which limit the absorption of metals by $C$. colocynthis roots. Since $C$. colocynthis is a perennial that self-propagates in mine tailings, is welladapted to the local conditions, and is a metal excluder ( $T F<1$ and $B C F<1)$; it is the best suitable plant for the re-vegetation and phytostabilization of polymetallic mine sites. 


\section{Acknowledgments}

This work was supported by the Pole of competences on Water and Environment (PC2E), and the European project SOWAEUMED (Network in Solid Waste and Water Treatment between Europe and Mediterranean Countries, contract no. 245843).

\section{Author Contributions}

These authors contributed equally to this work.

\section{Competing Interests}

The authors have declared that no competing interests exist.

\section{References}

1. Agboola O, Babatunde DE, Fayomi OS, Sadiku ER, Popoola P, Moropeng L, et al. A review on the impact of mining operation: Monitoring, assessment and management. RINENG. 2020; 8: 100181.

2. Rudke AP, de Souza VA, Dos Santos AM, Xavier AC, Rotunno Filho OC, Martins JA. Impact of mining activities on areas of environmental protection in the southwest of the Amazon: A GISand remote sensing-based assessment. J Environ Manage. 2020; 263: 110392.

3. Pehoiu G, Radulescu C, Murarescu O, Dulama ID, Bucurica IA, Teodorescu S, et al. Health risk assessment associated with abandoned copper and uranium mine tailings. Bull Environ Contam Toxicol. 2019; 102: 504-510.

4. Ali $\mathrm{H}$, Khan $\mathrm{E}$, Ilahi I. Environmental chemistry and ecotoxicology of hazardous heavy metals: Environmental persistence, toxicity, and bioaccumulation. J Chem. 2019; 2019: 6730305.

5. Mahar A, Wang P, Ali A, Awasthi MK, Lahori AH, Wang Q, et al. Challenges and opportunities in the phytoremediation of heavy metals contaminated soils: A review. Ecotoxicol Environ Saf. 2016; 126: 111-121.

6. Penido ES, Martins GC, Mendes TB, Melo LC, do Rosário Guimarães I, Guilherme LR. Combining biochar and sewage sludge for immobilization of heavy metals in mining soils. Ecotoxicol Environ Saf. 2019; 172: 326-333.

7. Wei Z, Van Le $Q$, Peng $W$, Yang $Y$, Yang $H, G u$, et al. A review on phytoremediation of contaminants in air, water and soil. J Hazard Mater. 2021; 403: 123658.

8. Shah V, Daverey A. Phytoremediation: A multidisciplinary approach to clean up heavy metal contaminated soil. Environ Technol Innov. 2020; 18: 100774.

9. Barbosa B, Fernando AL. Aided phytostabilization of mine waste. In: Bio-Geotechnologies for Mine Site Rehabilitation. Amsterdam: Elsevier; 2018. pp.147-157.

10. Zine H, Midhat L, Hakkou R, El Adnani M, Ouhammou A. Guidelines for a phytomanagement plan by the phytostabilization of mining wastes. Sci African. 2020; 10: e00654.

11. Mwaanga P, Silondwa M, Kasali G, Banda PM. Preliminary review of mine air pollution in Zambia. Heliyon. 2019; 5: e02485.

12. Yoon J, Cao X, Zhou Q, Ma LQ. Accumulation of $\mathrm{Pb}, \mathrm{Cu}$, and $\mathrm{Zn}$ in native plants growing on a contaminated Florida site. Sci Total Environ. 2006; 368: 456-464. 
13. Midhat L, Ouazzani N, Hejjaj A, Ouhammou A, Mandi L. Accumulation of heavy metals in metallophytes from three mining sites (Southern Centre Morocco) and evaluation of their phytoremediation potential. Ecotoxicol Environ Saf. 2019; 169: 150-160.

14. Al-Snafi AE. Chemical constituents and pharmacological effects of Citrullus colocynthis-a review. IOSR J Pharm. 2016; 6: 57-67.

15. Kumar S, Kumar D, Saroha K, Singh N, Vashishta B. Antioxidant and free radical scavenging potential of Citrullus colocynthis (L.) Schrad. methanolic fruit extract. Acta Pharm. 2008; 58: 215-220.

16. Ullah N, Khan MA, Asif AH, Khan T, Ahmad W. Citrullus colocynthis failed to combat against renal derangements, in spite of its strong antioxidant properties. Acta Pol Pharm. 2013; 70: 533-538.

17. Rajamanickam E, Gurudeeban S, Ramanathan T, Satyavani K. Evaluation of anti inflammatory activity of Citrullus colocynthis. Int J Curr Res. 2010; 2: 67-69.

18. Shafaei H, Esmaeili A, Rad JS, Delazar A, Behjati M. Citrullus colocynthis as a medicinal or poisonous plant: A revised fact. J Med Plant Res. 2012; 6: 4922-4927.

19. González V, Salinas J, García I, del Moral F, Simón M. Using marble sludge and phytoextraction to remediate metal (loid) polluted soils. J Geochem Explor. 2017; 174: 29-34.

20. Bolan N, Kunhikrishnan A, Thangarajan R, Kumpiene J, Park J, Makino T, et al. Remediation of heavy metal (loid) s contaminated soils-to mobilize or to immobilize? J Hazard Mater. 2014; 266: 141-166.

21. Melgar-Ramírez R, González V, Sánchez JA, García I. Effects of application of organic and inorganic wastes for restoration of sulphur-mine soil. Water Air Soil Pollut. 2012; 223: 61236131.

22. Tozsin G, Arol Al, Oztas T, Kalkan E. Using marble wastes as a soil amendment for acidic soil neutralization. J Environ Manage. 2014; 133: 374-377.

23. Tozsin G, Oztas T, Arol Al, Kalkan E, Duyar O. The effects of marble wastes on soil properties and hazelnut yield. J Clean Prod. 2014; 81: 146-149.

24. Zornoza R, Faz Á, Carmona DM, Acosta JA, Martínez-Martínez S, de Vreng A. Carbon mineralization, microbial activity and metal dynamics in tailing ponds amended with pig slurry and marble waste. Chemosphere. 2013; 90: 2606-2613.

25. Midhat L, Ouazzani N, Hejjaj A, Bayo J, Mandi L. Phytostabilization of polymetallic contaminated soil using Medicago sativa L. in combination with powdered marble: Sustainable rehabilitation. Int J Phytoremediation. 2018; 20: 764-772.

26. Aubert G. Méthodes d'analyses des sols. 2nd ed. Marseille: Centre régional de Documentation Pédagogique; 1978. pp.191.

27. Walkley A, Black IA. An examination of the Degtjareff method for determining soil organic matter, and a proposed modification of the chromic acid titration method. Soil Sci. 1934; 37 : 29-38.

28. Olsen SR, Sommers LE. Phosphorus. In: Methods of Soil Analysis: Part 2 Chemical and Microbiological Properties. 2nd ed. Madison: American Society of Agronomy; 1982. pp.403430.

29. Bremner JM. Nitrogen-total. In: Methods of Soil Analysis: Part 3 Chemical Methods. Madison: Soil Science Society of America; 1996. pp.1085-1121.

30. Elabbas S, Mandi L, Berrekhis F, Pons MN, Leclerc JP, Ouazzani N. Removal of Cr (III) from 
chrome tanning wastewater by adsorption using two natural carbonaceous materials: Eggshell and powdered marble. J Environ Manage. 2016; 166: 589-595.

31. Padmavathiamma PK, Li LY. Phytoremediation technology: Hyper-accumulation metals in plants. Water Air Soil Pollut. 2007; 184: 105-126.

32. Zhuang P, Yang QW, Wang HB, Shu WS. Phytoextraction of heavy metals by eight plant species in the field. Water Air Soil Pollut. 2007; 184: 235-242.

33. Simon L. Soil pollution, soil remediation. Budapest: Környezetgazdálkodási Intézet; 1999. pp.221.

34. Hakkou R, Benzaazoua $M$, Bussière B. Acid mine drainage at the abandoned Kettara mine (Morocco): 1. Environmental characterization. Mine Water Environ. 2008; 27: 145-159.

35. Hakkou $R$, Benzaazoua $M$, Bussière $B$. Acid mine drainage at the abandoned Kettara mine (Morocco): 2. Mine waste geochemical behavior. Mine Water Environ. 2008; 27: 160-170.

36. Alvarenga P, Gonçalves AP, Fernandes RM, De Varennes A, Vallini G, Duarte E, et al. Evaluation of composts and liming materials in the phytostabilization of a mine soil using perennial ryegrass. Sci Total Environ. 2008; 406: 43-56.

37. Tordoff GM, Baker AJ, Willis AJ. Current approaches to the revegetation and reclamation of metalliferous mine wastes. Chemosphere. 2000; 41: 219-228.

38. Krämer U. Metal hyperaccumulation in plants. Annu Rev Plant Biol. 2010; 61: 517-534.

39. Baker AJ. Accumulators and excluders-strategies in the response of plants to heavy metals. J Plant Nutr. 1981; 3: 643-654.

40. Mendez MO, Maier RM. Phytostabilization of mine tailings in arid and semiarid environmentsan emerging remediation technology. Environ Health Perspect. 2008; 116: 278-283.

41. Kabata-Pendias A, Pendias H. Trace Elements in Soils and Plants. 3rd ed. Boca Raton: CRC Press; 2001.

42. Rodriguez JH, Wannaz ED, Salazar MJ, Pignata ML, Fangmeier A, Franzaring J. Accumulation of polycyclic aromatic hydrocarbons and heavy metals in the tree foliage of Eucalyptus rostrata, Pinus radiata and Populus hybridus in the vicinity of a large aluminium smelter in Argentina. Atmospheric Environ. 2012; 55: 35-42.

43. Conesa HM, Faz Á, Arnaldos R. Heavy metal accumulation and tolerance in plants from mine tailings of the semiarid Cartagena-La Unión mining district (SE Spain). Sci Total Environ. 2006; 366: 1-11.

44. Abreu MM, Magalhaes MCF. Phytostabilization of soils in mining areas. Case studies from Portugal. In: Soil remediation. New York: Nova Science Publishers; 2009. pp.297-344.

45. Monaci F, Leidi EO, Mingorance MD, Valdés B, Oliva SR, Bargagli R. Selective uptake of major and trace elements in Erica andevalensis, an endemic species to extreme habitats in the Iberian Pyrite Belt. J Environ Sci. 2011; 23: 444-452.

46. Shi X, Zhang X, Chen G, Chen Y, Wang L, Shan X. Seedling growth and metal accumulation of selected woody species in copper and lead/zinc mine tailings. J Environ Sci. 2011; 23: 266-274.

47. Zhang YF, He LY, Chen ZJ, Wang QY, Qian M, Sheng XF. Characterization of ACC deaminaseproducing endophytic bacteria isolated from copper-tolerant plants and their potential in promoting the growth and copper accumulation of Brassica napus. Chemosphere. 2011; 83: 57-62. 


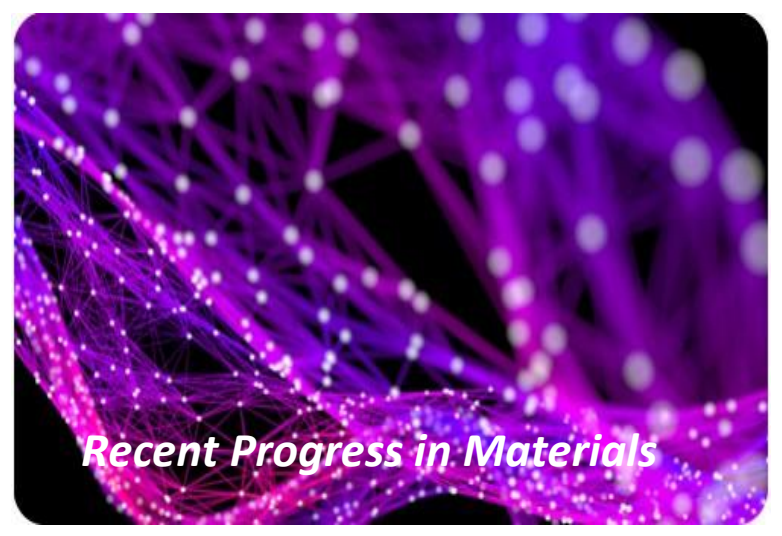

Enjoy Recent Progress in Materials by:

1. Submitting a manuscript

2. Joining in volunteer reviewer bank

3. Joining Editorial Board

4. Guest editing a special issue

For more details, please visit:

http://www.lidsen.com/journals/rpm 